\title{
Short communication: Phenotypic and genetic effects of the polled haplotype on yield, longevity, and fertility in US Brown Swiss, Holstein, and Jersey cattle
}

\section{J. B. Cole* and D. J. Null}

Animal Genomics and Improvement Laboratory, Agricultural Research Service, USDA, Beltsville, MD 20705-2350

\begin{abstract}
Phenotypes from the December 2018 US national genetic evaluations were used to compute effects of the polled haplotype in US Brown Swiss (BS), Holstein (HO), and Jersey (JE) cattle on milk, fat, and protein yields, somatic cell score, single-trait productive life, daughter pregnancy rate, heifer conception rate, and cow conception rate. Lactation records pre-adjusted for nongenetic factors and direct genomic values were used to estimate phenotypic and genetic effects of the polled haplotype, respectively. No phenotypic or direct genomic values effects were different from zero for any trait in any breed. Genomic PTA (gPTA) for the lifetime net merit $(\mathrm{NM} \$)$ selection index of bulls born since January 1, 2012, that received a marketing code from the National Association of Animal Breeders (Madison, WI), and cows born on or after January 1, 2015, were compared to determine whether there was a systematic benefit to polled or horned genetics. Horned bulls had the highest average gPTA for $\mathrm{NM} \$$ in all 3 breeds, but that difference was significant only in $\mathrm{HO}$ and JE (HO: $615.4 \pm 1.9$, JE: $402.3 \pm 3.4$ ). Homozygous polled BS cows had significantly higher average gPTA for NM\$ than their heterozygous polled or horned contemporaries $(\mathrm{PP}=261.4 \pm 43.5, \mathrm{Pp}=166.1 \pm 13.7, \mathrm{pp}=$ $174.1 \pm 1.8)$, but the sample size was very small $(\mathrm{n}=$ 9). In HO and JE, horned cows had higher gPTA for $\mathrm{NM} \$(\mathrm{HO}=378.3 \pm 0.2, \mathrm{JE}=283.3 \pm 0.3)$. Selection for polled cattle should not have a detrimental effect on yield, fertility, or longevity, but these differences show that, in the short term, selection for polled over horned cattle will result in lower rates of genetic gain.
\end{abstract}

Key words: genomic evaluation, phenotypic effects, polled

Received February 22, 2019.

Accepted May 3, 2019.

*Corresponding author: john.cole@ars.usda.gov

\section{Short Communication}

The rapid growth in the number of genotyped dairy cattle, which recently surpassed 3 million in the United States, has resulted in the identification of several recessive disorders, permitted the determination of carrier status of genotyped animals using haplotypes in place of laboratory tests (Cole et al., 2018) and enabled the calculation of haplotype effects on production and fitness traits (Cole et al., 2016). Schafberg and Swalve (2015) provide a comprehensive history of polled cattle, and there is increasing interest in the polled phenotype (e.g., Thompson et al., 2017) for purposes of improving animal welfare. Soller et al. (1963) reported an association between polledness and infertility in male Saanen goats, and there are anecdotal reports that polled dairy cattle have reduced fertility compared with their horned counterparts. Several studies have shown that polled and horned cattle have similar genetic merit for calving, health, growth, and reproduction traits (Frisch et al., 1980; Kommisrud and Steine, 1997; Goonewardene et al., 1999a,b; Lamminger et al., 2000). However, polled Holstein cattle were shown to have lower average genetic merit than their horned contemporaries (Spurlock et al., 2014; Windig et al., 2015). The purpose of this study was to determine the phenotypic and genetic effects of the polled haplotype in the US Brown Swiss (BS), Holstein (HO), and Jersey (JE) breeds on 8 yield and fitness traits.

The data used in this analysis consisted of phenotypes and direct genomic values (DGV) from the December 2018 US national genetic evaluation for genotyped daughters of genotyped bulls in the US Brown Swiss, Holstein, and Jersey breeds. This ensured that polled haplotype status was known for both cows and bulls. The 8 traits included in this study were milk, fat, and protein yields, SCS, single-trait productive life (PL), daughter pregnancy rate (DPR), heifer conception rate $(\mathbf{H C R})$, and cow conception rate $(\mathbf{C C R})$. Cows were required to have phenotypes for all traits in the analysis, and the data set included all lactations in the 
Table 1. Number of unique bulls and cows included in each data set by breed and polled haplotype status

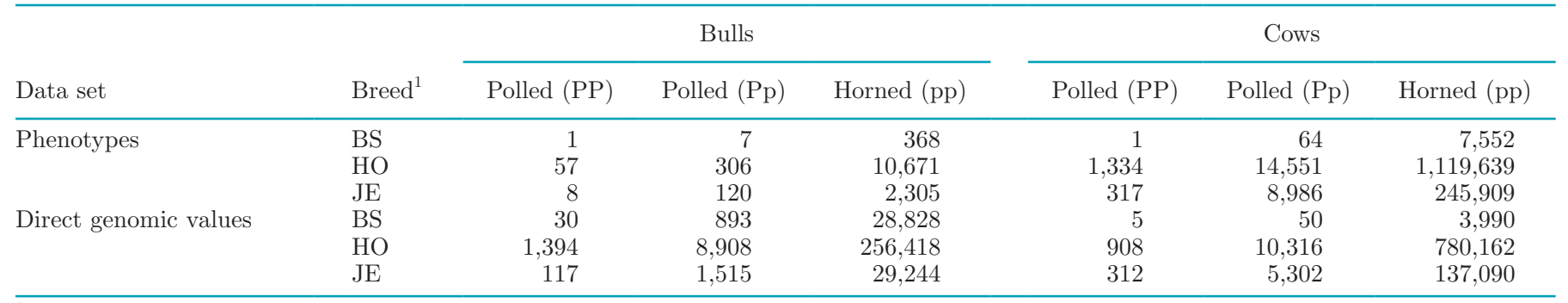

${ }^{1} \mathrm{BS}=$ Brown Swiss, $\mathrm{HO}=$ Holstein, and $\mathrm{JE}=$ Jersey.

database except for PL and HCR, which have single (lifetime) values. Genotypes for all cows were imputed to a common set of 79,294 SNP used for US genomic evaluations with findhap.f90 version 3 (VanRaden et al., 2011). Counts of bulls and cows by breed and polled haplotype status are provided in Table 1.

Two distinct mutations on chromosome 1 are responsible for polledness in taurine dairy cattle. The 80-kb Friesian deletion is responsible for most polled Holstein and Jersey cattle (Rothammer et al., 2014), whereas the 212-bp Celtic indel is responsible for most polled beef and dual-purpose cattle (Medugorac et al., 2012). Polled status is sent by the genotyping laboratories but their reports do not distinguish between the 2 mutations, and older genotyping arrays included only SNP tracking the Friesian mutation. Most chips now include the Celtic haplotype, too, but a single tag SNP at 2,578,598 bp on chromosome 1 is used to track both mutations in the US population. It is possible, in principle, to determine the specific polled mutation carried by an animal but, in practice, it is much easier to track and distribute to the industry general status (polled/horned) rather than the individual mutation carried. Most animals included in this study had direct genotypes $(\mathrm{BS}=3,918 ; \mathrm{HO}=787,995 ; \mathrm{JE}=142,239)$ rather than imputed genotypes $(\mathrm{BS}=127 ; \mathrm{HO}=3,391$; $\mathrm{JE}=465)$.

A fixed-effects model was fitted to phenotypic and genetic values for all traits using PROC GLM in SAS 9.4 (TS1M2) for Linux (SAS Institute Inc., Cary, NC):

$$
y_{i j k}=\mu+\text { sire }_{j}+\text { status }_{k}+e_{i j k},
$$

where $y_{i j k}$ is the phenotypic value or DGV for each of the 8 traits evaluated for cow $i, \mu$ is the overall mean, sire $_{j}$ is the fixed effect of the cow's sire, status $k$ is the fixed effect of the polled haplotype (coded as 0,1 , or 2 copies of the minor, or polled, allele), and $e_{i j k}$ is the random residual error term. Sire effects were absorbed, and the polled haplotype effect was tested for differences using a $t$-test. Phenotypes were pre-adjusted for nongenetic (factors by subtracting management group, parity-sex, and herd-by-sire effects from each observation. The DGV were calculated as the sum of individual SNP effects from the December 2018 genomic evaluation (Wiggans et al., 2011) plus breed- and traitspecific intercepts (Cole and Null, 2013). A within-trait Bonferroni adjustment was used to correct for multiple comparisons, and significance was declared when $P<$ 0.0028 .

Genomic PTA (gPTA) for the lifetime net merit selection index (NM\$; VanRaden et al., 2018) of bulls born since January 1, 2012, that received a marketing code from the National Association of Animal Breeders (Madison, WI), and cows born on or after January 1, 2015, were also compared to determine whether there was a systematic benefit to polled or horned genetics. Bulls were restricted to those marketed because many young males are genotyped but never have semen available for sale, so they do not contribute to genetic trend in the next generation. Cows were selected to represent a cohort of contemporary animals that have had the opportunity to complete their first lactations.

The effects of the polled haplotype on the phenotypic and genetic values of the 8 traits are shown in Tables 2 and 3 , respectively. The $P$-values were adjusted on a within-trait basis to account for multiple comparisons. Of the 24 phenotype tests conducted, none were significant at the 0.0028 level (Bonferroni-adjusted within trait) or higher. None of the 24 DGV effects were different from zero. A significant haplotype effect would not necessarily indicate a causal relationship, and an association of a genotype with trait differences could be due to hitchhiking. For example, Peñagaricano and Khatib (2012) found evidence that alleles with deleterious fertility effects are associated with milk protein genes and concluded that the observed effects may be due to hitchhiking. These results are consistent with the findings of Gehrke et al. (2016), who reported that polled Holstein cattle in Germany had lower milk, fat, and protein yields than their horned contemporaries. Dressel et al. (2016) also found that polled German Holsteins had lower breeding values for milk yield and total merit index. 
Table 2. Effect of the polled haplotype on phenotypes pre-adjusted for nongenetic factors of milk, fat, and protein yields, SCS, single-trait productive life $(\mathrm{PL})$, daughter pregnancy rate $(\mathrm{DPR})$, heifer conception rate (HCR), and cow conception rate (CCR)

\begin{tabular}{|c|c|c|c|c|c|c|c|c|c|}
\hline Breed $^{1}$ & Statistic & \multicolumn{8}{|c|}{ Trait } \\
\hline \multirow{2}{*}{$\mathrm{BS}$} & Effect & -277.11 & -0.86 & -4.75 & 0.31 & -2.26 & -4.73 & 11.22 & -2.52 \\
\hline & $\mathrm{SE}$ & 902.33 & 35.28 & 24.98 & 0.56 & 4.66 & 6.70 & 21.57 & 1.90 \\
\hline \multirow[t]{2}{*}{$\mathrm{HO}$} & $\mathrm{N}$ & $1,135,524$ & $1,135,524$ & $1,135,524$ & $1,109,327$ & 396,166 & 615,215 & 615,215 & 615,215 \\
\hline & Effect & 25.11 & -2.99 & -1.28 & 0.06 & -0.55 & 0.82 & 4.87 & -0.01 \\
\hline \multirow{2}{*}{ JE } & Effect & 13.78 & 1.40 & 1.74 & 0.003 & 0.62 & -0.85 & -6.25 & 0.74 \\
\hline & $\mathrm{SE}$ & 27.82 & 1.76 & 1.24 & 0.031 & 0.90 & 1.42 & 3.87 & 0.65 \\
\hline
\end{tabular}

${ }^{1} \mathrm{BS}=$ Brown Swiss, $\mathrm{HO}=$ Holstein, and JE $=$ Jersey.

Horned bulls had the highest average gPTA for NM\$ in all 3 breeds, but that difference was significant $(P<$ 0.05 ) only in HO and JE (HO: $615.4 \pm 1.9$, JE: 402.3 \pm 3.4 ; Table 4). Homozygous polled (PP) BS cows had significantly higher average gPTA for $\mathrm{NM} \$(P<0.05)$ than their heterozygous polled $(\mathrm{Pp})$ or horned $(\mathrm{pp})$ contemporaries $(\mathrm{PP}=261.4 \pm 43.5, \mathrm{Pp}=166.1 \pm$ 13.7, $\mathrm{pp}=174.1 \pm 1.8$; Table 4$)$, but the sample size was very small $(\mathrm{n}=9)$. In $\mathrm{HO}$ and $\mathrm{JE}$, horned cows had higher gPTA for NM $\$(P<0.05 ; \mathrm{HO}=378.3 \pm 0.2, \mathrm{JE}$ $=283.3 \pm 0.3$; Table 4$)$. These differences suggest that, in the short term, selection for polled over horned cattle will result in lower rates of genetic gain. However, this could change rapidly if consumers and milk processors demand that management practices change to eliminate the need for disbudding. In such a case, the polled haplotype could have enough value to offset losses in lifetime profit attributable to increased production.

These results show that there is no association of the polled haplotype with yield, longevity, or fertility in US BS, HO, or JE cattle. Selection for polled cattle in these breeds is unlikely to have a detrimental effect on performance unless polled families trace back to a narrow genetic base and genetic load accumulates in those lines. However, the small pool of available polled animals limits the selection pressure that can be applied to that subpopulation and will result in lower rates of genetic gain (e.g., Windig et al., 2015) until more polled bulls are available. Advanced reproductive or gene editing technologies (e.g., Mueller et al., 2019) can be used to increase the frequency of polled animals in these breeds without undesirable effects on the traits studied.

\section{ACKNOWLEDGMENTS}

The Council on Dairy Cattle Breeding (Bowie, MD) and the Cooperative Dairy DNA Repository (Verona, WI) are acknowledged for providing data used in this study. The authors were supported by appropriated project 8042-31000-002-00, "Improving Dairy Animals by Increasing Accuracy of Genomic Prediction, Evaluating New Traits, and Redefining Selection Goals," of the Agricultural Research Service of the United States Department of Agriculture (USDA). Mention of trade names or commercial products in this article is solely for the purpose of providing specific information and does not imply recommendation or endorsement by the

Table 3. Effect of the polled haplotype on direct genomic values of milk, fat, and protein yields, SCS, single-trait productive life (PL), daughter pregnancy rate (DPR), heifer conception rate (HCR), and cow conception rate (CCR)

\begin{tabular}{|c|c|c|c|c|c|c|c|c|c|}
\hline Breed $^{1}$ & Statistic & \multicolumn{8}{|c|}{ Trait } \\
\hline \multirow[t]{2}{*}{ BS } & $\mathrm{N}$ & 4,045 & 4,045 & 4,045 & 4,045 & 4,045 & 4,045 & 4,045 & 4,045 \\
\hline & SE & 45.44 & 1.72 & 1.26 & 0.03 & 0.42 & 0.33 & 0.33 & 0.30 \\
\hline \multirow[t]{2}{*}{$\mathrm{HO}$} & $\mathrm{N}$ & 791,386 & 791,386 & 791,386 & 791,386 & 791,386 & 791,386 & 791,386 & 791,386 \\
\hline & Effect & 3.82 & -0.03 & 0.10 & -0.004 & 0.05 & 0.05 & 0.06 & 0.07 \\
\hline \multirow{2}{*}{ JE } & Effect & 4.04 & -0.35 & 0.02 & -0.001 & -0.05 & 202.08 & 0.06 & -0.08 \\
\hline & SE & 5.13 & 0.20 & 0.14 & 0.003 & 0.04 & 0.04 & 0.04 & 0.03 \\
\hline
\end{tabular}

${ }^{1} \mathrm{BS}=$ Brown Swiss, $\mathrm{HO}=$ Holstein, and $\mathrm{JE}=$ Jersey. 
Table 4. Least squares means of genomic predicted transmitting ability for lifetime net merit (\$) of homozygous polled (PP), heterozygous polled (Pp), and horned (pp) bulls born on or after January 1, 2012, and cows born on or after January 1, 2015, by breed ${ }^{1}$

\begin{tabular}{|c|c|c|c|c|c|c|c|c|c|}
\hline Sex and breed ${ }^{1}$ & \multicolumn{3}{|c|}{ Polled (PP) } & \multicolumn{3}{|c|}{ Polled (Pp) } & \multicolumn{3}{|c|}{ Horned (pp) } \\
\hline $\mathrm{BS}$ & 3 & 211.7 & 73.3 & 12 & 262.3 & 36.6 & 275 & 273.5 & 7.6 \\
\hline $\mathrm{HO}$ & 171 & $422.5^{\mathrm{c}}$ & 16.2 & 510 & $488.3^{\mathrm{b}}$ & 9.4 & 12.095 & $615.4^{\mathrm{a}}$ & 1.9 \\
\hline $\mathrm{JE}$ & 11 & $311.3^{\mathrm{B}}$ & 43.6 & 113 & $374.4^{\mathrm{B}}$ & 13.6 & 1,825 & $402.3^{\mathrm{A}}$ & 3.4 \\
\hline \multicolumn{10}{|c|}{ Cows born $\geq$ January 1, 2015} \\
\hline $\mathrm{JE}$ & 665 & $257.5^{\mathrm{c}}$ & 5.2 & 8,799 & $272.7^{\mathrm{b}}$ & 1.4 & 198,489 & $283.3^{\mathrm{a}}$ & 0.3 \\
\hline
\end{tabular}

${ }^{\mathrm{a}-\mathrm{c}}$ Means with different letters within a row differed $(P<0.01)$.

${ }^{\mathrm{A}, \mathrm{B}}$ Means with different letters within a row differed $(P<0.05)$.

${ }^{1} \mathrm{BS}=$ Brown Swiss, $\mathrm{HO}=$ Holstein, and JE $=$ Jersey.

USDA. The USDA is an equal opportunity provider and employer. Two anonymous reviewers are thanked for their thoughtful suggestions, which greatly improved the quality of the manuscript.

\section{REFERENCES}

Cole, J. B., and D. J. Null. 2013. Visualization of the transmission of direct genomic values for paternal and maternal chromosomes for fifteen traits in U.S. Brown Swiss, Holstein, and Jersey cattle. J. Dairy Sci. 96:2713-2726. https://doi.org/10.3168/jds.2012-6008.

Cole, J. B., D. J. Null, and P. M. VanRaden. 2016. Phenotypic and genetic effects of recessive haplotypes on yield, longevity, and fertility. J. Dairy Sci. 99:7274-7288. https://doi.org/10.3168/jds.2015 $-10777$.

Cole, J. B., P. M. VanRaden, D. J. Null, J. L. Hutchison, T. A. Cooper, and S. M. Hubbard. 2018. AIP Research Report Genomic4: Haplotype tests for economically important traits of dairy cattle. Accessed February 20, 2019. https://aipl.arsusda.gov/reference/ haplotypes_ARR-G4.html.

Dressel, H., M. Wensch-Dorendorf, and H. H. Swalve. 2016. Genetic relationship between polledness and other relevant traits in Holstein dairy cattle. Page 491 in Proc. 67th Ann. Mtg. European Assoc. Animal Prod., Belfast, UK. European Assoc. Animal Prod., Rome, Italy.

Frisch, J. E., H. Nishimura, K. J. Cousins, and H. G. Turner. 1980. The inheritance and effect on production of polledness in four crossbred lines of beef cattle. Anim. Prod. 31:119-126.

Gehrke, L., D. Seichter, I. Ruß, I. Medugorac, J. Tetens, and G. Thaller. 2016. Impact of the Friesian POLLED mutation on milk production traits in Holstein Friesian. Page 434 in Proc. 67th Annu. Mtg. European Assoc. Animal Prod., Belfast, UK. European Assoc. Animal Prod., Rome, Italy.

Goonewardene, L. A., H. Pang, R. T. Berg, and M. A. Price. 1999a. A comparison of reproductive and growth traits of horned and polled cattle in three synthetic beef lines. Can. J. Anim. Sci. 79:123-127. https://doi.org/10.4141/A98-096.

Goonewardene, L. A., M. A. Price, M. F. Liu, R. T. Berg, and C. M. Erichsen. 1999b. A study of growth and carcass traits in dehorned and polled composite bulls. Can. J. Anim. Sci. 79:383-385.

Kommisrud, E., and T. Steine. 1997. Semen collection, semen production and fertility rates in polled vs horned bulls in Norway. Reprod. Domest. Anim. 32:221-223. https://doi.org/10.1111/j.1439 -0531.1997.tb01285.x.

Lamminger, A., H. Hamann, G. Röhrmoser, E. Rosenberger, H. Kräusslich, and O. Distl. 2000. Relationships between polledness and traits used in the breeding objectives for German Fleckvieh. Zuchtungskunde 72:325-339.

Medugorac, I., D. Seichter, A. Graf, I. Russ, H. Blum, K. H. Göpel, S. Rothammer, M. Förster, and S. Krebs. 2012. Bovine polledness - An autosomal dominant trait with allelic heterogeneity. PLoS One $7: \mathrm{e} 39477$.

Mueller, M. L., J. Cole, T. Sonstegard, and A. Van Eenennaam. 2019. Comparison of gene editing vs. conventional breeding to introgress the POLLED allele into the U.S. dairy cattle population. J. Dairy Sci. 102:4215-4226. https://doi.org/10.3168/jds.2018-15892.

Peñagaricano, F., and H. Khatib. 2012. Association of milk protein genes with fertilization rate and early embryonic development in Holstein dairy cattle. J. Dairy Res. 79:47-52. https://doi.org/10 $.1017 /$ S0022029911000744.

Rothammer, S., A. Capitan, E. Mullaart, D. Seichter, I. Russ, and I. Medugorac. 2014. The $80-\mathrm{kb}$ DNA duplication on BTA1 is the only remaining candidate mutation for the polled phenotype of Friesian origin. Genet. Sel. Evol. 46:44.

Schafberg, R., and H. H. Swalve. 2015. The history of breeding for polled cattle. Livest. Sci. 179:54-70.

Soller, M., M. Laor, R. Barnea, Y. Weiss, and N. Ayalon. 1963. Polledness and infertility in male Saanen goats. J. Hered. 54:237-240. https://doi.org/10.1093/oxfordjournals.jhered.a107256.

Spurlock, D. M., M. L. Stock, and J. F. Coetzee. 2014. The impact of 3 strategies for incorporating polled genetics into a dairy cattle breeding program on the overall herd genetic merit. J. Dairy Sci. 97:5265-5274. https://doi.org/10.3168/jds.2013-7746.

Thompson, N. M., N. O. Widmar, M. M. Schutz, J. B. Cole, and C. A. Wolf. 2017. Economic considerations of breeding for polled dairy cows versus dehorning in the United States. J. Dairy Sci. 100:4941-4952. https://doi.org/10.3168/jds.2016-12099.

VanRaden, P. M., J. B. Cole, and K. L. Parker Gaddis. 2018. AIP Research Report NM $\$ 7$. Net merit as a measure of lifetime profit: 2018 revision. Accessed April 22, 2019. https://aipl.arsusda.gov/ reference/nmcalc-2018.htm.

VanRaden, P. M., J. R. O'Connell, G. R. Wiggans, and K. A. Weigel. 2011. Genomic evaluations with many more genotypes. Genet. Sel. Evol. 43:10. https://doi.org/10.1186/1297-9686-43-10.

Wiggans, G. R., P. M. VanRaden, and T. A. Cooper. 2011. The genomic evaluation system in the United States: Past, present, future. J. Dairy Sci. 94:3202-3211. https://doi.org/10.3168/jds.2010 -3866 .

Windig, J. J., R. A. Hoving-Bolink, and R. F. Veerkamp. 2015. Breeding for polledness in Holstein cattle. Livest. Sci. 179:96-101. https: //doi.org/10.1016/j.livsci.2015.05.021. 